\section{Doctor Jekyll \\ and Architect Hyde: \\ Investigating the Double Nature of Architectural Teachers Within Polytechnic Schools}

Since the foundation of polytechnic schools, design has been a critical feature of polytechnic culture, which aims at transforming the world. Herbert Simon $(1969,111)$ identified the main task of engineering schools in changing the existing situations into a different state with desirable features:

Historically and traditionally, it has been the task of the science disciplines to teach about natural things: how they are and how they work. It has been the task of engineering schools to teach about artifici I things: how to make artefacts that have desired properties and how to design. Engineers are not the only professional designers. Everyone designs who devises courses of action aimed at changing existing situations into preferred ones. [...] Design, so construed, is the core of all professional training; it is the principal mark that distinguishes the professions from the sciences.

Although the concept of design is a site of common ground for polytechnic schools, how it is used and conceived of within the training of architects and engineers has been under discussion since the birth of the first enginee ing schools in France and Germany.

Thus, this work is intended to look at the different epistemological assumptions held by the polytechnic institutions as a way to recognize common ground and differences among approaches to conceiving the design action in training and roles that teachers assume. In order to provide some interpretative elements to tackle these issues, this work is an analysis of different critical moments in the history of schools of architecture and engineering: the years from the French Revolution until the foundation of the Ecole des Beaux-Arts, and passing through the Bauhaus experience.

\section{TECHNICAL RATIONALITY AS THE GROUND FOR TRAINING IN} DESIGN

In the first half of the eighteenth century, the Ecole des Ponts et Chausées was established to make possible an overall control of the French territory. Subjects such as geometry and math were meant to be the students' tools to design the infrastructure of the "absolute monarchy." Teachers were asked to transmit theoretical knowledge, whereas students would focus on design and predicted outcomes (for instance, the cost to lay a mile of road based on a given cross-section): apprenticeships and "learning by doing" processes were just not taken into consideration (Saints, 2008).

With the foundation of the Ecole Polytechnique, this transformation toward a design-based approach was initiated. Jean-Nicolas-Louis Durand set up a school in contrast with the century-old co-optation system that underpinned the activity of the Academie Royale.

The approach developed in France at the beginning of the revolutionary years thus saw the introduction of a well-defined corpus of scientific subjects: physics, math, geometry, and technical drawing, among others, permeated the curriculum, whereas design action found a place at the end of the training path in the form of exercises (Figure 1).
Daniele

Campobenedetto

Politecnico di Torino
Caterina Barioglio

Politecnico di Torino

(2) 


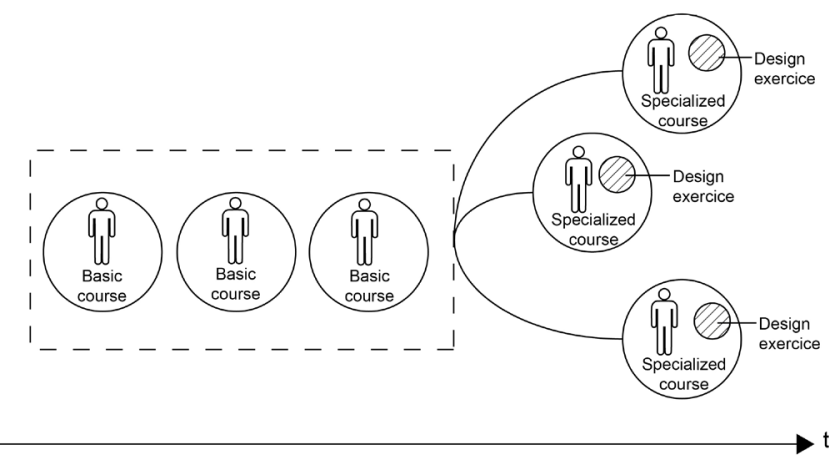

Figure 1. Ecole des Ponts et Chaussées teaching paradigm

This was a pivotal moment for the teacher's role, which shifted from that of a professional working on actual projects with students/apprentices toward an intellectual transmitting methodologies of works combining theoretical seminars with experiments in laboratories and practical works.

In this context, the teacher is often (and increasingly) a specialized researcher who is asked to deal with defined problems in which a set of values and final go Is are not at stake.

\section{DESIGNING IN A COMMUNITY OF PRACTICE}

During the first decade of the nineteenth century, the system established by the Ecole Polytechnique and the Ecole des Ponts et Chaussées showed its weaknesses. The consequent birth of the Ecole des Beaux-Arts was an attempt to draw a boundary between two different emerging professions: the architect and the engineer (Picon, 1988; Saints, 1983).

In this context, the Patron's systems (each Atelier was led by a signific nt architect who was considered a Maestro) and the competitions based on the design of public buildings established a new role for the architectural scholar.

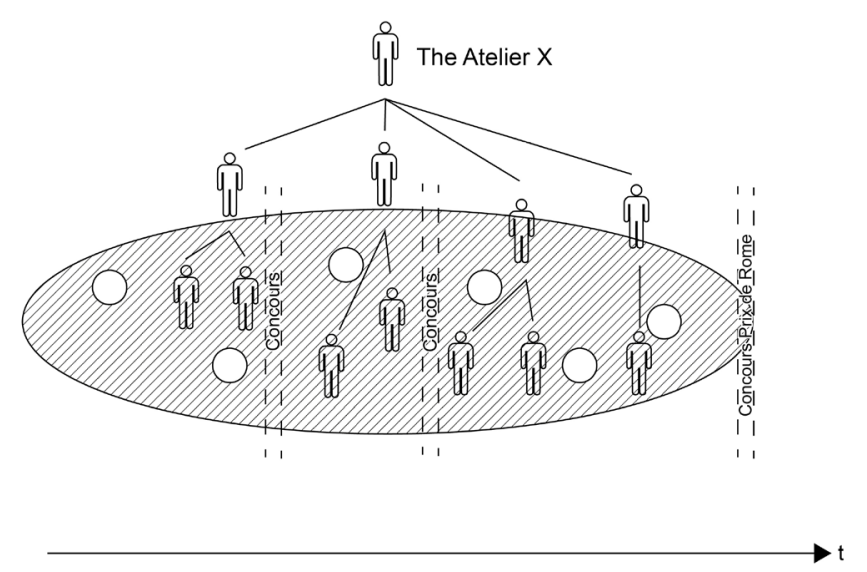

Figure 2. Ecole des Beaux-Arts teaching paradigm
The Atelier was, therefore, in between the apprenticeship (with the Maestro and a strict hierarchy among students with different experiences) and the intellectualization of design practice that started within the Ecole des Ponts et Chausées (Middleton, 1982).

Within the Atelier's activity, knowledge and competencies were intertwined in the same training environment in which the transmission of specific knowledge was meant to be instrumental to the design challenges that were set by the Concours system. The Patrons were practitioners, and they were at the top of a complicated hierarchical structure, designed to allow for the preparation of the Concours, in which older and younger students interacted according to a precise social structure (Figure 2).

In the midst of the turn from the eighteenth to the nineteenth century, the design teacher's role was split between two models: one looking at design practice and skills as a critical activity, and the other looking at abstract knowledge in order to standardize the design process.

\section{KNOWLEDGE AND KNOW-HOW}

After more than a century of this structure, the Bauhaus was an attempt to recombine the separation. The Staatliche Bauhaus was the outcome of a long reforming effort of the German school of applied arts, rooted at the end of the nineteenth century. Founded in 1919 as the fusion of the two existing institutions of Weimar (the old Academy of Fine Arts and the Kunstgewerbeschule), the Bauhaus was a compromise between their two ideological statements: the traditional art-academy and the workshops-based approaches (Wingler, 1962). The school was labelling itself as "economically useful and inventive," but the attempt to create an interdisciplinary reconciliation of art, technology, architecture, and engineering did not ultimately succeed (Saint, 2008). Nevertheless, the Bauhaus aimed to change arts and crafts education to address the needs and means of the modern era, and it drew attention to professional training, focusing on building and craft as a practical, social, and symbolic action in the real world.

This approach became tangible, especially after 1922, as it moved toward a reconciliation of craftsmanship design with industrial production (Gropius, 1935). Developed by Walter Gropius in 1922, the well-known wheel diagram clarifies the interdependence between theoretical-formal teaching and the practical work done in the Bauhaus workshops. Although the teaching style was less systematic than the one suggested by Gropius's schemes, the diagram reflects the teacher's role in recombining the artistic-intellectual dimension with the practical design-based one.

Vorkurs was the course that all the students had to pass after the first year. It was the checkpoint for teachers to control-and debatethe necessary knowledge and fundamentals of the whole school. After that, students were admitted to one of the individual workshops, which were considered the core of the educational path. In these workshops, technical and formal experiments were carried out, and students were apprentices working hands-on with qualified artisans to produce prototypes for industrial manufacturing and other clients.

Workshops were integrated with theoretical bases of specific disciplines (technology on materials and working tools and the general 


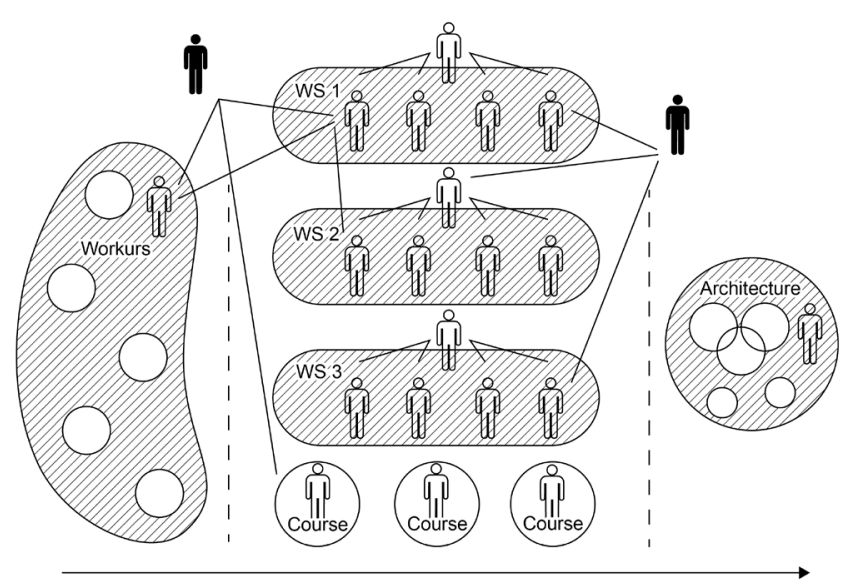

Figure 3. Bauhaus teaching paradigm

basis of company management are two examples). The architectural teaching was intended as a final synthesis of all these experiences, but it did not become active until just after 1927 (Figure 3).

Using an expression of Giulio Carlo Argan (1988), the Bauhaus was an example of a democratic school because it was based on the principle of collaboration between teachers and students: conceived as a small social organization, it aimed to achieve the perfect unity of the teaching method and the production system. This was exemplified in the workshops, where students and teachers would work together also to produce prototypes for industrial manufacturing, in collaboration with real clients.

\section{CONTEMPORARY ITALIAN POLYTECHNIC SCHOOLS}

How has this history affected the current Italian context? Nowadays, schools of architecture inside polytechnic institutions are and have been in an unusual position: two different teaching approaches, theoretical and project-based, permeate the whole educational path. Italian polytechnic schools host specialist and technical courses that pay tribute, in terms of method, to the Ecole Polytechnique, whereas the architectural Atelier has its roots in the Ecole des Beaux-Arts, and courses such as industrial design look at the Bauhaus experience.

Thus, differences in how design plays a role within training are embedded in polytechnic schools' DNA. The engineer's training path is still mainly based on a corpus of scientifi knowledge, followed by a progressive specialization, in which the design activities seem to be confined to exercises and experiments within the disciplinary boundaries. Project-based and challenge-based experiences have been introduced to address the increasing complexity of the profession. Nevertheless, they often remain supplementary to the training path, and are often voluntary or elective. In this context, design teachers are usually specialized researchers whose teaching mission is oriented toward problem-solving (whereas the research mission is increasingly dealing with complex problems through interdisciplinary approaches).

On the other hand, the Architectural Atelier (or Design Unit) in Italian polytechnic schools changed over time compared to the Beaux-
Arts model. During the nineteenth century, there was an attempt to disassemble the knowledge embedded in the architectural design process. In Italian architectural schools, this approach was evident in the training path that was comprised of:

- $\quad$ an early phase conceived of as "architectural grammar" in which students had to pass through analytical courses (architectural elements such as surveys, drawing, and descriptive geometry) and face underlying architectural design themes.

- a final part of the training path in which students had to face the problem of "synthesis": more complex architectural issues that involved social, technical, and cultural aspects.

- interpretative/critical teachings introduced in between these two learning layers, starting from the 1930s (an example was "Distributive Characters of Buildings") (Figure 4).

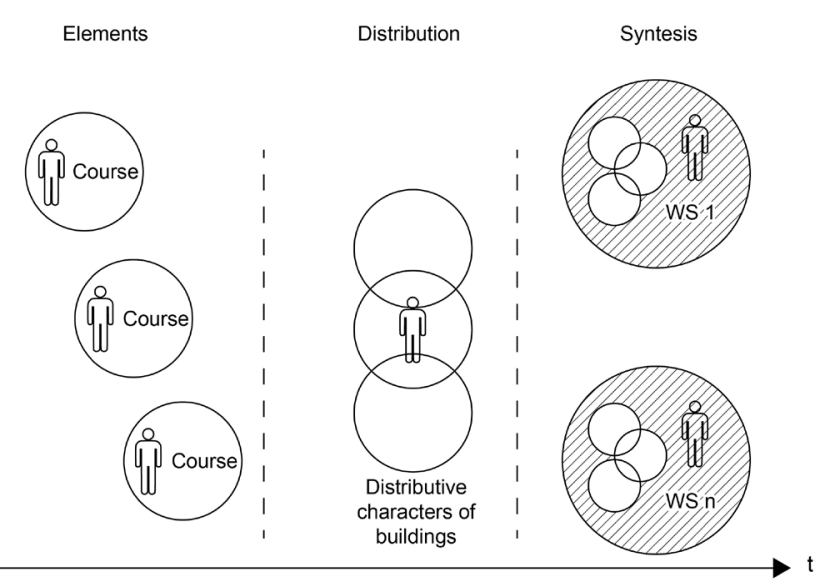

Figure 4. Nineteenth century Italian schools of architecture teaching paradigm

Except for the ending part of the training path (expressly dedicated to internships and activities for the final dissertation), architectural design activities are, in recent times, mostly organized into thematic design units supported by more traditional disciplinary courses. Some of these courses directly feed on the Ateliers' experimenting and interdisciplinary perspective to face the design challenge.

In this system, the architectural design teacher takes the role of a director who organizes and coordinates the dialogue between tutors of different disciplines toward a shared goal (Figure 5).

To look at the different epistemological assumptions held by the polytechnic institutions and to face them through a broader discussion that goes beyond teaching practices is thus proposed as a way to make interdisciplinary teachings effective. In this challenge, the role of teachers themselves is fundamental because of their ability to continuously adjust the boundaries between the different assumptions involved and to intertwine them within the polytechnic culture. 

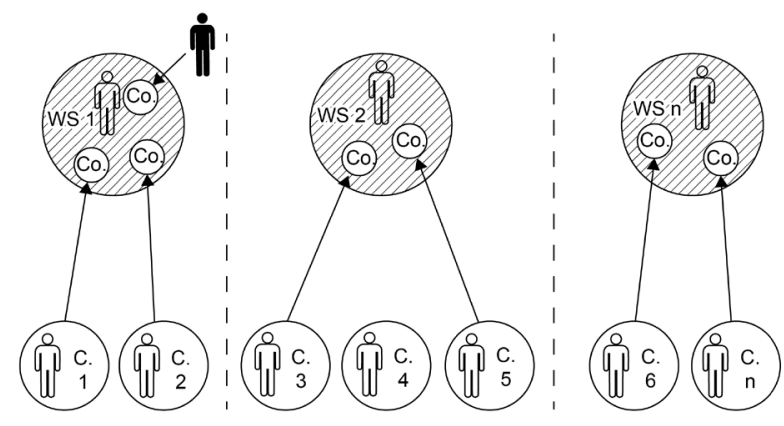

Figure 5. Evolution of the teaching paradigm in Italian schools of architectur

\section{CONCLUSIONS: A NEED FOR MUTUAL RECOGNITION}

The abovementioned different approaches to design teaching can be described in an imaginary space in which the design processes (spiral versus linear, where spiral processes have values and goals at stake, whereas linear processes do not) and the roles of teachers (moving from researcher to practitioner) are taken into account (Figure 6).

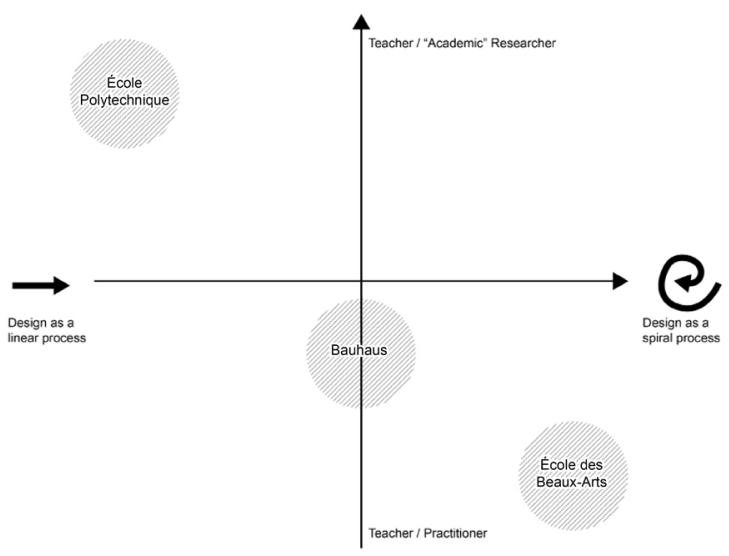

Figure 6. Analysis of the paradigms in relation to teaching design processes and teachers roles

design is taught in engineering, architecture, industrial design, and planning training paths, and teachers coming from different disciplines are used to approaching design teaching from different perspectives.

Within polytechnic teachings, these natures are in some ways forced to be used together for the common goal of "changing the existing situations into preferred ones," often working autonomously and without common ground.

However, in a context in which the defini ion of profession is increasingly uncertain, and interdisciplinarity and transdisciplinarity are identified as crucial tools for training and research activities, the mutual recognition of the different natures of approaches to design cannot be avoided.
This recognition is vital in order to ground a discussion of the role that design practice has in teaching methods and the role of teachers in shaping these methods.

Within the Italian context, we can spot some changes in the boundaries of polytechnic schools' design training. Social sciences erupted within the polytechnic culture: the approaches based on technical rationality are increasingly looking at this issue because of the major challenges posed by wicked problems even in engineering sciences (Figure 7).

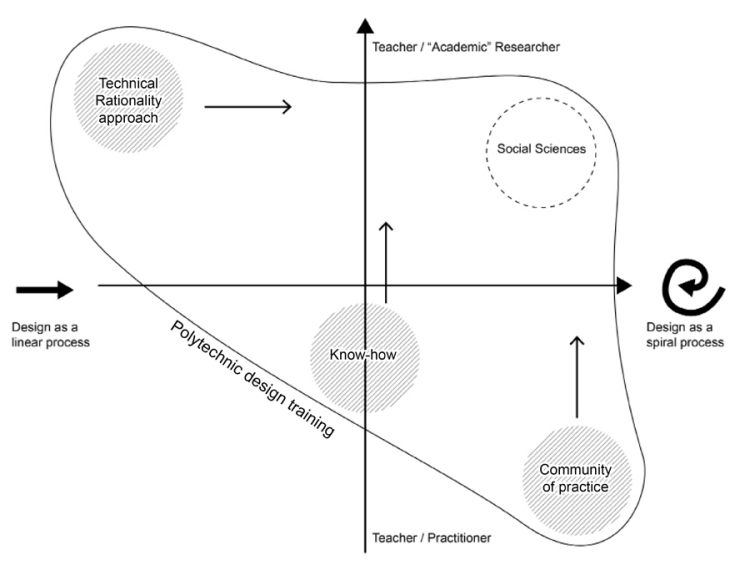

Figure 7. Scheme of the contemporary polytechnic teaching culture in Italy

assume scientific methods from the social sciences to create common ground to start a discussion including those approaches that were traditionally based on technical rationality (i.e., engineering).

This attempt to create common ground raises some questions that, to conclude, could be considered in our agendas in order to drive the changes in design teaching to address the changing professional de nitions:

Is it possible to share a conception of design teaching within polytechnic schools?

What is the design teacher's role in connecting methods and disciplines?

Do all these issues concern only architects?

\section{REFERENCES}

-Annie, J. (1986) La carrière de l'architecture au XIX siècle, Rèunion des Musées Nationaux.

-Argan, G.C. (1988) Walter Gropius e la Bauhaus, Torino, Einaudi. -Franciscono, M. (1971) Walter Gropius and the creation of the Bauhaus in Weimar, Chicago-London, Urbana, University of Illinois Press. -Gropius, W. (1935) The New Architecture and the Bauhaus, London, Faber and Faber.

-Hahn, P. (1988) Experimental Bauhaus, Berlin, Bauhaus Archive. 
-Middleton, R. (Ed.) (1982) The Beaux-Arts and Nineteenth-Century French Architecture, London, Thames and Hudson.

- Ministère de la Culture et de la Communication, des Grands Travaux et du Bicentenaire (1989) Les architectes de la liberté 1789-1799, Paris, Ecole Nationale Supérieure des Beaux-Arts.

-Picon, A. (1988) Architectes et Ingénieurs au Siècle des Lumières, Marseille, Editions Parenthèses.

-Robiglio, M. (2018) "Malthus, Giovannoni e il nostro futuro. Le Scuole di Architettura italiane in un contesto globale", in Rassegna di architettura e urbanistica, n. 154, pp. 8-18.

-Saints, A. (1983) The Image of the Architect, New Heaven, Yale University Press.

-Saints, A. (2008) Architect and Engineer: A Study in Sibling Rivalry, New Heaven, Yale University Press.

-Simon, H. (1969) The Sciences of the Artifici I, Cambridge, MIT

Press.

-Szambien, W. (1986) Les projets de l'an II, Parigi, Ecole nationale supérieure des beaux-arts.

-(1975) The Architecture of the Ecole des Beaux-Arts. The Museum of Modern Art, New York, MIT Press.

-Wingler, H.M. (1962) Das Bauhaus 1919-1933. Weimar, Dessau,

Berlin und die Nachfolge in Chicago seit 1937, Köln, Gebundenes

Buch. 